\title{
Recurrent Lung Non-Squamous Non- Small Cell Carcinoma
}

National Cancer Institute

\section{Source}

National Cancer Institute. Recurrent Lung Non-Squamous Non-Small Cell Carcinoma.

NCI Thesaurus. Code C128797.

The reemergence of non-squamous non-small cell lung carcinoma after a period of remission. 